\title{
Evaluation of Poverty Reduction in Nigeria towards Millennium Development Goals (MDGs)
}

\author{
Yisau, Tunde Mojeed \\ Department of Urban and Regional Planning, College of Environmental Sciences, \\ Bells University of Technology, PMB 1015 Ota, Ogun State, Nigeria
}

\begin{abstract}
Nigeria is one of the largest oil and gas producers in the world. These minerals and other resources have put Nigeria in a position of a wealthy nation. Yet Nigeria is one of the poorest nations in the world today because majority of the population (69.1\%) still live in abject poverty (UN, 2011)[1]. Although several ideas, plans, programmes and strategies have been domestically generated to address the scourge; but the persistence of poverty in large scale shows ineffective in government interventionist measures. In an attempt to deal with the problem of poverty, Nigeria as a member of the United Nations signed on to the implementation of Millennium Development Goals (MDGs) which also seeks to eradicate extreme hunger and poverty by 2015. This led to the formulation of the National Economic Empowerment and Development Strategy (NEEDS). NEEDS as a policy is targeted at eradicating poverty and bringing about sustainable development which is done through the establishment of agencies like National Poverty Eradication Programme (NAPEP). However, the current progress towards the attainment of the goals is approximately at a snail's pace and quixotic. The paper therefore sets to evaluate the poverty reduction in Nigeria via the instrumentality of the MDGs.
\end{abstract}

Keywords: Millennium Development Goals (MDGs), NEEDS, Poverty reduction

\section{INTRODUCTION}

Eradicating poverty is regarded as the most important goal of human development. Indeed, it is now widely believed that at its core, development must be about improvement of human well-being, removal of hunger, disease and promotion of productive employment for all (Edoh, 2003[2]; Kankwanda, 2002[3]; Mahammed, 2006[4]). Reducing poverty levels in the third world is still the most difficult development issue facing the international community. In spite of poverty-reduction strategies embarked upon by the global community to meet the Millennium Development Goals (MDGs), only China and India have made considerable progress, and succeeded in ensuring that the goal of halving poverty by the year 2015 in the world is met. In these two countries, the proportion of people living on less than $\$ 1$ a day by 2015 was projected to decrease to just over $12 \%$ from more than $28 \%$, bringing half of a billion people out of poverty (World Bank, 2004)[5]. In Sub-Saharan Africa, the situation is even worse; the number of people living in absolute poverty is slated to increase.

Nigeria as a case study, the poverty situation is galloping. Despite several attempts by successive governments to ameliorate the scourge, Eze (2009: 447)[6] explains that the level of poverty is geometrically increasing (see also Okpe and Abu, 2009: 205)[7]. Poverty is deep and pervasive, with about $69.1 \%$ of the population living in absolute poverty (UN, 2011)[1]. The country is rich but the people are poor. The country is blessed with abundant natural and human resources. Nigeria should rank among the richest countries that should not suffer from poverty entrapment. However, the monumental increase in the level of poverty has made the socio-economic landscape frail and fragile. Today, Nigeria is ranked among the poorest countries in the world.

With the recognition of poverty as a common denominator in the global community, the MDGs were adopted in September 2000. According to Omideyi (2007)[8], the United Nations (UN) made its millennium declaration, stating that:

"We will spare no effort to free our fellow men, women, and children from the abject and dehumanizing conditions of extreme poverty to which more than a billion of them are currently subjected"

MDGs are aimed at eradicating the extreme poverty and hunger by 2015 using 1990 as the baseline. The target are to help the proportion of people whose income is less than 1 US dollar a day, the proportion of people who suffer from hunger is also expected to be halved, productive employment and decent work for all (Central Bank of Nigeria, 2003)[9]. As a member of the UN, Nigeria keyed into the MDGs and subsequently produced a policy document called the National Economic Empowerment and Development Strategy (NEEDS) in 2004 to further see to the achievement of the MDGs (NPC, 2004)[10]. Specifically NEEDS has the following actionable goal: 
- Wealth creation

- Employment generation

- Poverty reduction

- Value re-orientation

The NEEDS as a national policy was intended to meet some of the goals of the MDGs, especially poverty reduction. In assessing the performance of MDGs and NEEDS in Nigeria, especially when it relates to poverty eradication, one can say without fear of contradiction that MDGs have performed below the expectations of Nigerians. The failure to effectively combat the problem has largely been blamed on poor leadership, infrastructural decay, lack of adequate data base, endemic corruption, policy inconsistency, and poor governance and accountability (Okonjo-Iweala, Soludo and Muhtar, 2003:1)[11]. It is at the backdrop of this realization that this paper is set to examine the MDGs and poverty eradication as it is geared towards bringing sustainable development in Nigeria. The main purpose of the study is to evaluate the poverty reduction in Nigeria via the instrumentality of the MDGs with a view to study the impact of NEEDS towards the poverty reduction and attainment of MDGs. The specific objectives are to:

- Examine the incidence of poverty in Nigeria;

- Identify poverty reduction strategies and the impacts of government intervention;

- Assess MDGs in line with poverty reduction/eradication in Nigeria;

- Proffer pragmatic suggestions towards poverty reduction in Nigeria.

This paper, however, addresses three main questions viz:

- Is there poverty in Nigeria and to what extent?

- Does the NEEDS, as a policy, address the poverty scourge in Nigeria?

- What is the Nigeria progress and current status toward MDGs target (particularly goal 1)?

\section{CONCEPTUAL DISSECTION OF POVERTY}

There is no unanimously accepted definition of poverty. As a matter of fact it is almost never defined in itself, but through other concepts, such as growth, well-being, exclusion or equity. A basic feature of the concept of poverty is its complex and multidimensional nature which makes the plurality of definitions inescapable. As a result, Eze (2009:446)[6] submits that there is a plethora of literature on the concept of poverty. On this basis, Maxwell (1999:2)[12] asks a number of agitating questions bordering on the current terminology of poverty. Is poverty simply about the level of income obtained by households or individuals? Is it about lack of access to social services? Or is it more correctly understood as the inability to participate in society economically, socially, culturally and politically? This implies that the broader the definition of poverty the more difficult is its measurement.

According to Free English Dictionary [13], the word 'poverty' refers to the state of being very poor. Similar words (synonyms) for poverty include beggary, bankruptcy, debt, destitution, hardship indigence and insolvency, penury, privation, want, dearth, insufficiency, lack, paucity and shortage. Apparently, these are words of negative or bad connotations which make poverty altogether undesirable phenomenon. The dictionary meaning is a general definition, lacking in specificity contextually. In a more operational sense, WeisfeldAdams (2008: 2)[14] categorized poverty into income poverty and human poverty. The former is understood as living with low income, low consumption, poor nutrition and poor living conditions. Human poverty, on the other hand, describes the conditions of low health and low education.

The multidimensionality of poverty has been stressed and succinctly expressed in the Copenhagen Declaration on Social Development that Poverty has various manifestations, including: "lack of income and productive resources sufficient to ensure sustainable livelihoods; hunger and malnutrition; ill health; limited or lack of access to education and other basic services; increased morbidity and mortality from illness; homelessness and inadequate housing; unsafe environments, social discrimination and exclusion; lack of participation and exclusion; lack of participation in decision-making and in civil, social and cultural life" (UN, 1995)[15].

UNICEF (2005)[16] identifies certain basic needs, such as food, clothing, shelter, basic health and education, and essential services that must absolutely be fulfilled to keep people out of poverty. Poverty, in this sense, is defined as deprivation in the material requirements (goes far beyond a lack of private income) for minimally acceptable fulfilment of human needs, including food. UNDP (2006)[17] on the other hand draws on several other definitions, integrates their fundamental elements and enhances the process with a focus on the concept of a lack of capabilities. The concept, aptly referred to as human poverty, defines poverty as a state of deprivation or denial of the basic choices and opportunities needed to enjoy a decent standard of living, to live a long, healthy, constructive life and to participate in employment and in the social, political and cultural life of the community. 
The juxtaposition of the conceptual analysis above and the practical reality in Nigeria reveal that there is high-level mass and pervasive poverty in the country. This explains why the attainment of the MDGs and poverty reduction in Nigeria require massive efforts from governments at all levels and other stakeholders including the international donors.

\section{THE NATURE AND INCIDENCE OF POVERTY IN NIGERIA}

Nigeria is the most populous country in Africa occupying an area of 923,768 square kilometres. It had an estimated population of 140,431,790 million in 2006 population census and the current projected population of 191,767,032 (World Population Review, June 2017)[18] with over 250 ethnic groups and four hundred languages and dialects. Administratively, Nigeria is a federation which has 36 states and a Federal Capital Territory (FCT) with 774 local government areas in the states and six area councils in FCT. The states are broadly grouped into six geopolitical zones namely: North Central, North East, North West, South East, South-South and South West zones.

Nigeria was one of the richest 50 countries in the early 1970s but has since retrogressed to become one of the 25 poorest countries at the threshold of the twenty first century (CDD, 2013)[19]. The pervasive poverty situation in Nigeria clearly betrays the high hopes at independence that the country would emerge as a major industrial haven in the world. The high hopes were hinged on the availability of abundant natural and material resources in the country. As noted by Ovwasa (2000:68)[20], evidence abounds to illustrate that Nigeria is a poor nation. This position is justified because a large percentage of the population lives below the poverty line. Poverty incidence map of Nigeria by state in 2004 with national average of 54.4 depicted more details as shown in Fig. 1.

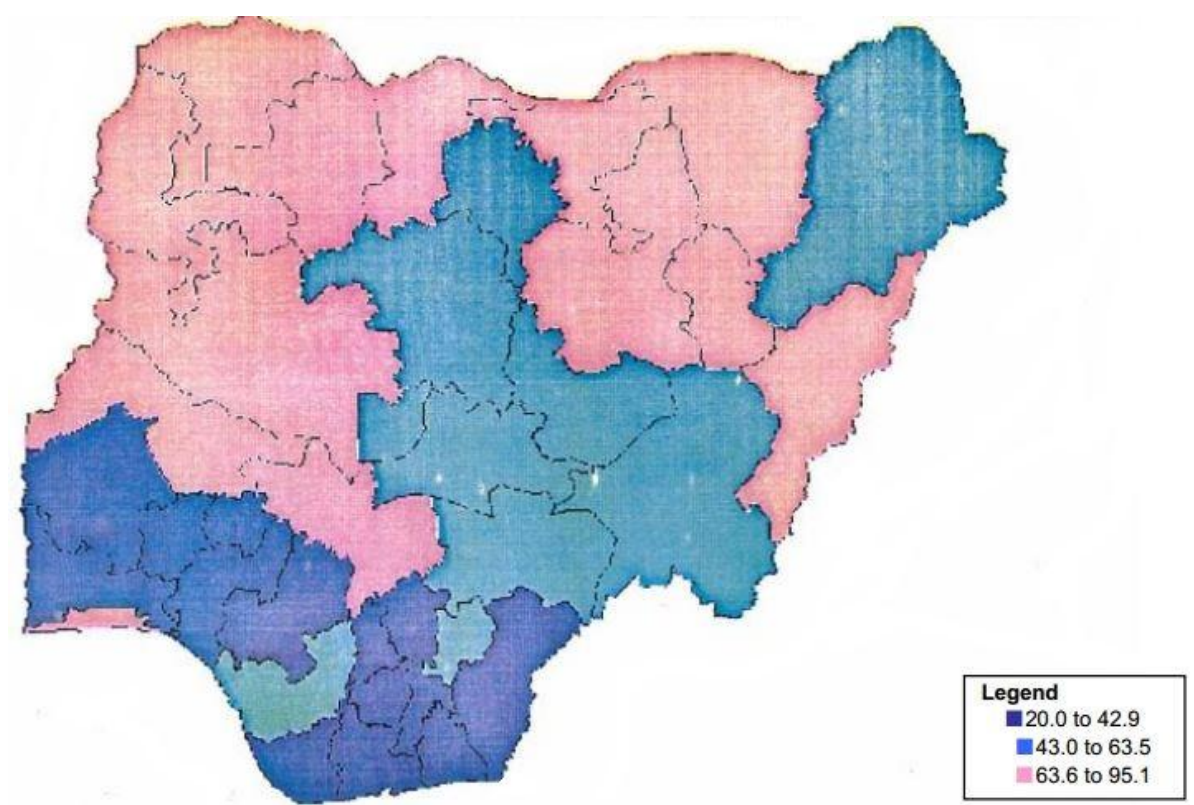

Figure 1: Poverty Incidence Map of Nigeria by State: 2004 (Source: NBS, 2011)[21]

Statistics from Table 1 shows that the incidence of poverty using the rate of US \$1 per day increased from $28.1 \%$ in 1980 to $46.3 \%$ in 1985 and declined to $42.7 \%$ in 1992 but increased again to $65.6 \%$ in 1996 . The incidence increased to $69.2 \%$ in 1997 . The 2004 report by the National Planning Commission (NPC) indicates that poverty has decreased to $54.4 \%$ but in 2010 , the poverty rate had increased again to $69.1 \%$. It is also observed that more than $50 \%$ of the population in all zones of the country lived in poverty in 1996 . Poverty was much more widespread in the Northern than the Southern parts of the country. Comparing the zones, the South East is the least poor while the Northwest zone is the poorest. These differences reflect, in part, the differences in natural resource endowments and levels of education between the north and the south as well as differences in the distribution of industries.

Table 1: Incidence of Poverty by Geo-political Zones

\begin{tabular}{|c|c|c|c|c|c|c|c|c|c|}
\hline Analytical Categories & \multicolumn{9}{|c|}{ Percentage } \\
\hline Year & 1980 & 1985 & 1986 & 1992 & 1996 & 1997 & 2004 & 2006 & 2010 \\
\hline North East & 35.6 & 54.9 & 53.2 & 54.0 & 70.1 & 68.0 & 72.2 & - & 76.3 \\
\hline North West & 37.7 & 52.1 & 48.4 & 36.5 & 77.2 & 62.0 & 71.2 & - & 77.7 \\
\hline
\end{tabular}


Evaluation of Poverty Reduction in Nigeria towards Millennium Development Goals (MDGs)

\begin{tabular}{|c|c|c|c|c|c|c|c|c|c|}
\hline North Central & 32.2 & 50.8 & 48.4 & 46.0 & 64.3 & 53.0 & 67.0 & - & 67.5 \\
\hline South East & 12.9 & 30.4 & 30.9 & 41.0 & 53.5 & 79.5 & 26.7 & - & 67.0 \\
\hline South West & 13.4 & 38.6 & 42.0 & 43.0 & 60.9 & 74.1 & 43.0 & - & 59.1 \\
\hline South-South & 13.2 & 45.7 & 38.0 & 40.8 & 58.2 & 78.6 & 35.1 & - & 63.7 \\
\hline National & $\mathbf{2 8 . 1}$ & $\mathbf{4 6 . 3}$ & $\mathbf{4 3 . 0}$ & $\mathbf{4 2 . 7}$ & $\mathbf{6 5 . 6}$ & $\mathbf{6 9 . 2}$ & $\mathbf{5 4 . 4}$ & $\mathbf{6 5 . 5}$ & $\mathbf{6 9 . 1}$ \\
\hline $\begin{array}{c}\text { Estimated Total Population } \\
\text { (Million) }\end{array}$ & 65.0 & 75.0 & - & 91.5 & 102.3 & - & 126.3 & - & 167.0 \\
\hline $\begin{array}{c}\text { Population in Poverty (Million) } \\
\text { Ponalion }\end{array}$ & 17.7 & 34.7 & - & 39.3 & 67.1 & - & 68.1 & - & 112.5 \\
\hline
\end{tabular}

Source: Culled from CDD, 2013[19] and AIAE, 2005[22]

Poverty in Nigeria is characterized by a worsening of inequality among the people. Compared with other countries, income inequality in Nigeria is widening. Igbuzor (2006)[23] observes that Nigeria is among the 20 countries in the world with the widest gap between the rich and the poor. According to World Bank (2008)[24], the total income earned by the richest $20 \%$ of the population in 2003 is $49.2 \%$ while the total income earned by the poorest $20 \%$ is $5.0 \%$. In terms of human development index, Nigeria is ranked 153th out of the 187 countries surveyed in 2013 with increase from 0.434 to 0.471 between 2005 and 2012 (UNDP, 2013)[25]. It is therefore evident that the large number of Nigerians living in poverty, the spatial dimensions of poverty in the country and the characteristics of the poor of the country, require that Nigeria should have a strategy to address poverty especially within the instrumentality of MDGs.

\section{MDGS AND POVERTY ERADICATION: ASSESSMENT OF STRATEGIES AND POLICIES}

Following the year 2000 Millennium Summit, Nigeria was among the 192 nation states who signed the Millennium Declaration outlining eight goals for global development by 2015. In Nigeria, these Millennium Development Goals (MDGs) has become central to the country's development agenda (Nigeria National Assembly, 2012)[26].

In reaction to the horrendous poverty crisis in Nigeria, a variety of public policies have been designed to tackle the problem of poverty and hunger. Measures taken to combat poverty and promote development in the country actually started at the beginning of Nigeria's statehood. At different points in time, various programmes were conceptualized and implemented with the hope that they will impact on poverty in the country. These include Operation Feed the Nation (OFN), Free and Compulsory Primary Education (FCPE), Green Revolution, Low Cost Housing, River Basin Development Authorities (RBDA), National Agricultural Land Development Authority (NALDA), Agricultural Development Programme (ADP), Agricultural Credit Guarantee Scheme (ACGS), Strategic Grains Reserves Programme (SGRP), Rural Electrification Scheme (RES) and Rural Banking Programme (RBP), Directorate for Food, Roads and Rural Infrastructure (DFRRI), National Directorate of Employment (NDE), Better Life Programme (BLP), People's Bank of Nigeria (PBN), Community Banks Programme, Family Support Programmes (FSP) and Family Economic Advancement Programme (FEAP) (see Garba, 2006[27]; Omotola, 2008:506[28]; Chukwuemeka, 2009:406[29]; Eze, 2009: $447[6])$

With the birth of democracy and inauguration of Nigeria's fourth republic in 1999, the Poverty Alleviation Programme (PAP) came on board as an interim antipoverty measure (Nwaobi, 2003:16) [30]. As observed by Chukwuemeka (2009:447)[29], the programme was targeted at correcting the deficiencies of the past efforts of alleviating poverty through the objective of providing direct jobs to 200,000 unemployed people (see also Obadan, 2001:166-167)[31]. Despite these antipoverty measures, poverty has consistently been on the increase in Nigeria, showing the ineffectiveness of the strategies and programmes.

Also worth mentioning programme targeted at achieving MDGs is the NEEDS, described as a medium term strategy. NEEDS is a national framework of action, which has its equivalent at the state and local government levels as State Economic Empowerment and Development Strategies (SEEDS) and Local Economic Empowerment and Development Strategies (LEEDS) respectively (AFPODEV, 2006)[32]. In fact, NEEDS has been described as the Nigerian version of the MDGs and has 'poverty reduction' as its third actionable goal (NPC,__: 13)[33]. In line with the policy thrust of NEEDS, the government set up the National Poverty Eradication Programme (NAPEP) to tackle the challenges of poverty. But since the establishment of NAPEP, it has nothing tangible to show for its existence. It is gathered and disheartening to discover that the agency, NAPEP, has received a total of 11.8 billion Naira (\$78.7million) but it has nothing to show for it (Edoh, 2003)[2].

As laudable as these programmes appear, poverty still remains endemic and pervasive in Nigeria. The poverty reduction or alleviation programme of the government via the instrumentality of the MDGs and NEEDS has failed because they lacked clearly defined policy framework with proper guidelines for poverty alleviation; they suffer from political instability, interference, policy and macroeconomic dislocations; and are 
riddled with corruption, political deception, outright kleptomania and distasteful looting (Garba, 2006)[27]. So MDGs has not successfully tackled the challenges of poverty in the country.

\section{POVERTY ERADICATION PROGRESS AND CHALLENGES IN NIGERIA: ACHIEVING THE MDGS IN 2015}

Nigeria's democratic experience has neither served the purpose of political emancipation nor led to economic betterment of the citizens. This is especially in the face of endemic poverty, hunger, unemployment and progressive disempowerment of a large chunk of the population. The prospect of escaping the life threatening situations and achieving sustainable growth and development was therefore linked to the MDGs. Although the MDGs were specifically adopted to deal with the challenge of extreme poverty and hunger and other developmental challenges in the midst of increasing global wealth and technological advances. Nigeria 2015 MDGs End-Point Report shows the goal was met. In particular, the indicators of the goal relating to hunger have been moving in the opposite direction in the last few years to the end-point as it is shown in Fig. 2 and Table 2.

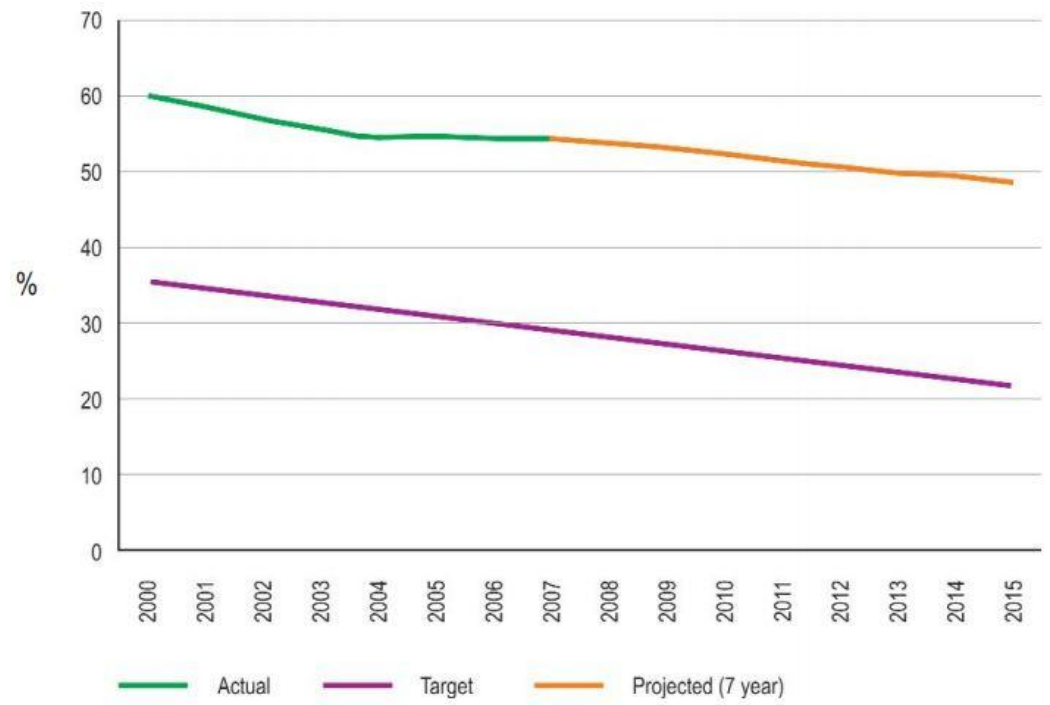

Figure 2: Actual and targeted poverty incidence in Nigeria. (Source: Government of the Federal Republic of Nigeria, 2010: 14)[34]

Table 2: MDG Goal 1 - Eradicate Extreme Poverty and Hunger: Nigeria Progress Report 2010

\begin{tabular}{|c|c|c|c|c|c|c|c|c|c|c|c|c|c|}
\hline Target & Indicators & 1990 & 2000 & 2001 & 2002 & 2003 & 2004 & 2005 & 2006 & 2007 & 2008 & 2009 & 2015 Target \\
\hline \multirow{3}{*}{$\begin{array}{c}\text { Halve, between } \\
1990 \text { and } 2015, \\
\text { the proportion } \\
\text { of people } \\
\text { whose income } \\
\text { is less than one } \\
\text { dollar a day }\end{array}$} & $\begin{array}{l}\text { 1.1 Proportion of } \\
\text { the population } \\
\text { living on less } \\
\text { than } \$ 1(\mathrm{PPP}) \text { per } \\
\text { day }(\%)\end{array}$ & NA & NA & NA & NA & NA & 51.55 & 51.55 & 51.55 & NA & NA & NA & 21.4 \\
\hline & $\begin{array}{l}1.2 \text { Poverty gap } \\
\text { ratio }\end{array}$ & 32.1 & NA & NA & NA & 29.6 & 29.6 & 29.6 & NA & NA & NA & NA & NA \\
\hline & $\begin{array}{c}\text { 1.3 Share of } \\
\text { poorest quintile in } \\
\text { national } \\
\text { consumption }(\%)\end{array}$ & 5.0 & 5.0 & 5.0 & 5.0 & 5.0 & 5.1 & NA & NA & NA & NA & NA & NA \\
\hline \multirow{2}{*}{$\begin{array}{l}\text { Halve, between } \\
1990 \text { and } 2015 \text {, } \\
\text { the proportion } \\
\text { of people who } \\
\text { suffer from } \\
\text { hunger }\end{array}$} & $\begin{array}{l}\text { 1.8 Prevalence of } \\
\text { underweight } \\
\text { children under five } \\
\text { years of age }(\%)\end{array}$ & 35.7 & 31 & 28.7 & 28.7 & 28.7 & 30 & 30 & NA & 25 & 23.1 & NA & 19.96 \\
\hline & $\begin{array}{l}\text { 1.9 Proportion of } \\
\text { population below } \\
\text { minimum level of } \\
\text { dietary energy } \\
\text { consumption }\end{array}$ & 39 & 29 & NA & NA & NA & 35 & 35 & 35 & 34.1 & 33.1 & 32.83 & 14.5 \\
\hline
\end{tabular}

Source: Government of the Federal Republic of Nigeria, 2010[34]

AFRODAD (2005: iv)[35] reports that despite rapid advances by some countries that the MDGs are achievable, most countries in sub-Saharan Africa including the populous nation of Nigeria are yet to mobilize resources, political and financial supports to meet specific global challenges, especially eradicating extreme poverty and hunger as depicted in Table 3. 
Table 3: MDGs 2013 Progress Chart

\begin{tabular}{|l|c|c|}
\hline \multirow{2}{*}{ Goal and Target } & \multicolumn{2}{|c|}{ Africa } \\
\cline { 2 - 3 } & Northern & Sub-Saharan \\
\hline Goal 1: Eradicate extreme poverty \\
\hline Reduce extreme poverty by half & $\begin{array}{c}\text { low } \\
\text { poverty }\end{array}$ & $\begin{array}{c}\text { very high } \\
\text { poverty }\end{array}$ \\
\hline Productive and decent employment & $\begin{array}{l}\text { large } \\
\text { deficit in } \\
\text { decent } \\
\text { work }\end{array}$ & $\begin{array}{c}\text { very large } \\
\text { deficit in } \\
\text { decent work }\end{array}$ \\
& low hunger & $\begin{array}{c}\text { very high } \\
\text { hunger }\end{array}$ \\
\hline Reduce hunger by half & \multicolumn{2}{|c}{} \\
\end{tabular}

Target already met or expected to be met by 2015.

Progress insufficient to reach the target if prevailing trends persist

Source: United Nations, 2013[36]

With the present state of affairs, the attainment of the MDGs benchmarked for 2015 was a daunting challenge. If the challenges are therefore not addressed, Nigerian may remain in the doldrums for a long time to come. However, it is worth remarking that certain feats have been achieved but the current rate of progress is approximately at a snail's pace. The detail of the situation in Nigeria at present trends shows that Nigeria is urgently required to pursue the implementation of the new Sustainable Development Goals (SDGs). All official reports indicate that Nigeria was unable to achieve goal one. For Nigeria to have attained target one, poverty is supposed to be reduced from $42 \%$ in 1990 to $21 \%$ in 2015 . But by 2010 , poverty was increased to $69.1 \%$ as shown in the table 1 . The progress towards achieving MDG goal 1 in 2015 was very slow, and five out of every ten Nigerians still live in poverty. Growth has not been sufficiently equitable or generated enough jobs to reduce poverty further. Fig. 3 shows that nutrition is low (undernourishment) if compared to other developing countries of the world (NPC, : 17)[33].

NPC in their report of countdown strategies to achieve MDGs in 2015 identified challenges specific to eradicating extreme hunger and poverty as:

- The lack of management capacity and access to affordable funds among small business entrepreneurs;

- The low level of agricultural mechanisation;

- The predominance of older people unfamiliar with modern technologies in agricultural production;

- Poor industrial processing and storage technology, resulting in high post-harvest losses and weak links with markets;

- $\quad$ Poor rural infrastructure, spurring migration and leading to high unemployment in urban areas;

- Huge under-investment in poverty alleviating projects, infrastructure and agricultural production in rural areas; and

- Poor water, sanitation and hygiene, leading to recurring diarrhoea and nematode infections, child malnutrition, low productivity and low incomes.
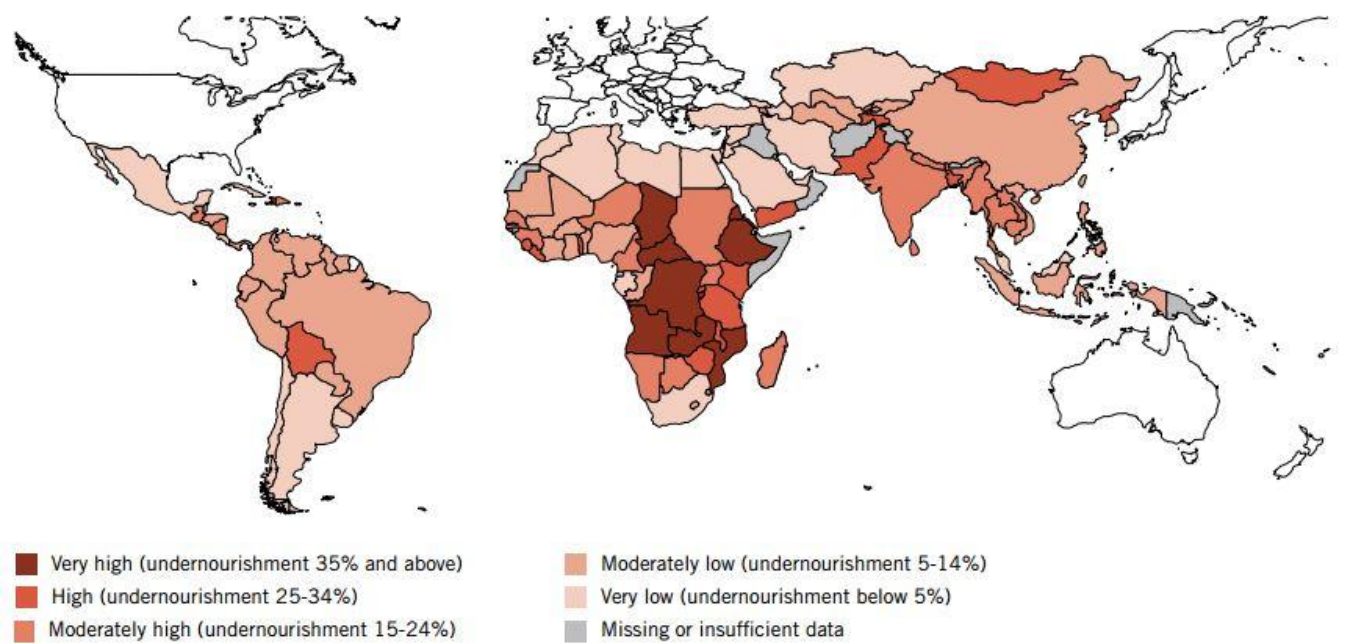

Figure 3: Proportion of undernourished population, 2005-2007 (percentage) (Source: United Nations, 2011)[1] 


\section{SUMMARY AND CONCLUSION}

Reducing poverty and hunger remains a key development challenge in Nigeria because the country hosts the largest population of poor people. From the 1980s, the poverty situation in Nigeria has been galloping as empirical studies have shown. Poverty is more endemic in the rural areas and the Northern zones still demonstrate no hope of escaping extreme poverty especially with the current problem of terrorism (Boko Haram) in the Northern part of the country. However, since independence, successive governments have made different attempts to combat the scourge, but the failure of the interventions explains the inherent limitations in domestically generated idea on poverty reduction. Sustainable growth is critical for poverty reduction. Broad based growth that creates jobs has great potential to reduce poverty. Past improvement in economic growth of Nigeria as the Africa's biggest economy has not brought about the desired reduction in poverty. Nigeria has to overcome significant gaps and challenges such as poor governance, official kleptocracy, weak legislative framework, poor budgeting culture among others in order to reduce poverty.

Eradicating poverty as step towards sustainable development in Nigeria via the MDGs framework continues to appear as a herculean task. As a result, Nigeria is off track in terms of achieving the MDGs and the year 2015 marks the end of the timeline for their achievement. However, the challenges of poverty and development remain daunting. The process of the post 2015 development agenda (SDGs) has started at the international level. It is therefore necessary to begin to think beyond 2015.

\section{RECOMMENDATIONS}

For sustainable development or poverty reduction to be availed in Nigeria, there is need to accelerate the growth of the economy, ensure a stable macroeconomic environment, address infrastructure gaps, ensure an enabling environment for a market-based, private sector driven economy, encourage production and use of local materials, and ensure pro-poor economic policies. There is also the need to develop long-term strategic plans that address unemployment, taking into consideration the educational curriculum and system. Eliminate the discrimination against rural and agricultural development. A continuous flow of resources need to be provided to agriculture and not absolutely depend on oil and gas industry. Finally, there is the need to fully integrate the MDGs in the national development strategy, vigorously pursue the implementation of the new SDGs and enhance monitoring thereof. There should be periodic and consistent reporting of the development for easy access of data.

\section{List of Abbreviations}

ACGS: Agricultural Credit Guarantee Scheme

ADP: Agricultural Development Programme

AIAE: African Institute for Applied Economics

BLP: Better Life Programme

CDD: Centre for Democracy and Development

DFRRI: Directorate for Food Roads and Rural Infrastructure

FCPE: Free and Compulsory Primary Education

FEAP: Family Economic Advancement Programme

FSP: Family Support Programmes

LEEDS: Local Economic Empowerment and Development Strategies

MDGs: Millennium Development Goals

NALDA: National Agricultural Land Development Authority

NAPEP: National Poverty Eradication Programme

NBS: National Bureau of Statistics

NDE: National Directorate of Employment

NEEDS: National Economic Empowerment and Development Strategy

NPC: National Planning Commission

OFN: Operation Feed the Nation

PAP: Poverty Alleviation Programme

PBN: People's Bank of Nigeria

RBDA: River Basin Development Authorities

RBP: Rural Banking Programme

RES: Rural Electrification Scheme

SDGs: Sustainable Development Goals

SEEDS: State Economic Empowerment and Development Strategies

SGRP: Strategic Grains Reserves Programme

UN: United Nations

UNDP: United Nations Development Programme

UNICEF: United Nations International Children's Emergency Fund 


\section{REFERENCES}

[1] UN, The millennium development goals report 2011 (New York, 2011). Retrieved from: http://www.un.org/millenniumgoals/pdf/(2011_E)\%20MDG\%20Report\%202011_Book\%20LR.pdf, accessed: 4 June, 2015.

[2] T. Edoh, Poverty and the survival of democracy in Nigeria, Nigerian Journal of Political and Administrative Studies, 1(4). 2003.

[3] M. Kankwanda, Poverty Eradication: Where Africa Stands (London: Economica, 2002).

[4] A. A. Mahammed, Reflections on the victory and crisis of democracy, in Saliu, et al (Eds), Democracy and development (University of Ilorin, Nigeria, 2006).

[5] World Bank, Yearly gazette (Abuja Central Bank of Nigeria, 2004).

[6] C. M. Eze, The privatized state and mass poverty in Nigeria: The factor of economic development programme since 1980s, African Journal of Political Science and International Relations 3(10), 2009, 443-450.

[7] I. J. Okpe and G. A. Abu, Foreign private investment and poverty reduction in Nigeria (1975-2003), Journal of Social Sciences 19(3), 2009, 205-211.

[8] A. K. Omideyi, Poverty and development in Nigeria: Trailing the MDGs, Afr. J. Infect. Dis. 1(1), 2007, 3 -17 .

[9] Central Bank of Nigeria, An appraisal of Federal Government NAPEP, Bullion 27, January-March, 2003.

[10] National Planning Commission, National Economic Empowerment and Development Strategy, (Communications Development Incorporated, Abuja, Nigeria, 2004).

[11] N. Okonjo-Iweala, C. C. Soludo, M. Muhtar, Introduction, in N. Okonjo-Iweala, C. C. Soludo, M. Muhtar (Eds), The debt trap in Nigeria: Towards a sustainable debt strategy, (Trenton: Africa World Press, Inc., 2003) 1-19.

[12] S. Maxwell, The meaning and measurement of poverty, ODI Poverty Briefing 3, February 1999. Retrieved from: http://www.odi.org.uk/resources/docs/3095.pdf, accessed: 15 May, 2016.

[13] Free English Dictionary: http://www.thefreedictionary.com/poverty, accessed: 4 June, 2015.

[14] Weisfeld-Adams, Emma and Andrzejewski, Anastasia, Hunger and poverty: Definitions and distinctions, (5 Union Square West, New York, The Hunger Project, 2008). Retrieved from: http://www.thp.org/files/Hunger\%20and\%20Poverty.pdf, accessed: 4 June, 2015.

[15] United Nations, Report of the world summit for social development, Copenhagen, International Institute for Sustainable Development, 10(44), 1995.

[16] UNICEF, Children living in poverty: A review of child poverty definitions, measurements, and policies, (New York: UNICEF, 2005). Retrieved from: http://www.unicef.org/policyanalysis/files/child_poverty_final_draft_4_05.pdf, accessed: 3 June, 2015.

[17] UNDP, What is poverty: Concepts and Measures, International Poverty Centre Journal, Poverty in Focus, Brazil. Retrieved from: http://www.ipc-undp.org/pub/IPCPovertyInFocus9.pdf, accessed: 15 June, 2015.

[18] World Population Review, http://worldpopulationreview.com/countries/nigeria-population/, accessed: 2 June, 2017.

[19] Centre for Democracy and Development, The Millennium Development Goals and poverty reduction in Nigeria: Progress, Prospects and Policy Implications, Final Report. Abuja, Nigeria.

[20] O. L. Ovwasa, Constraints on poverty alleviation in Nigeria, Political Science Review, Official Journal of the Department of Political Science, University of Ilorin, Nigeria 1(1), 2000, 56-80.

[21] National Bureau of Statistics, Poverty profile for Nigeria, in Federal Republic of Nigeria Gazette, Study for Poverty Profile (Africa), Final Report, 2011.

[22] African Institute for Applied Economics, Poverty reduction strategies towards the millennium development goals: Africa's experiences and lessons for Nigeria, Enugu Forum Policy Paper 2, 2005.

[23] O. Igbuzor, The millennium development goals: Can Nigeria meet the goals in 2015?, A Paper Presented at a Symposium on the Millennium Development Goals and Nigeria: Issues, Challenges and Prospects, Organized by the Institute of Chartered Accountants of Nigeria (ICAN), Abuja on 27th July, 2006.

[24] World Bank, World development indicators 2008, in: C. Ucha, Poverty in Nigeria: Some dimensions and contributing factors, Global Majority E-Journal, 1(1), 2008, 46-56.

[25] UNDP, Explanatory note on 2013 HDR composite indices of Nigeria, Human Development Report, 2013. Retrieved from: http://hdr.undp.org/sites/default/files/Country-Profiles/NGA.pdf, accessed: 25 May, 2015.

[26] Nigeria National Assembly, Review of the institutional structures and processes related to the MDGs in the parliament of Nigeria, Review of Inter-Parliamentary Union, 2012. Retrieved from: http://www.ipu.org/splz-e/unga13/nigeria.pdf, accessed: 20 May, 2015. 
[27] A. Garba, Alleviating poverty in Northern Nigeria, A Paper Presented at the Annual Convention of Zumunta Association, USA Minneapolis, MN, July 28-29, 2006.

[28] J. S. Omotola, Combating poverty for sustainable human development in Nigeria: The continuing struggle, Journal of Poverty, 12(4), 2008, 496-517.

[29] E. E. O. Chukwuemeka, Poverty and the millennium development goals in Nigeria: The nexus, Educational Research and Review, 4(9), 2009, 405-410.

[30] G. C. Nwaobi, Solving the poverty crisis in Nigeria: An applied general equilibrium approach, Quantitative Economic Research Bureau, Gwagwalada, Abuja, 2003.

[31] M. I. Obadan, Poverty reduction in Nigeria: The way forward, CBN Economic and Financial Review 39(4), 2001, 159-188.

[32] AFPODEV, Impact of population growth on the attainment of the millennium development goals in Nigeria, AFRODEV Abuja, Nigeria, 2006.

[33] NPC, Nigeria - millennium development goals (MDGs), countdown strategy 2010 to 2015: Achieving the MDGs, Abuja, Nigeria, undated. Retrieved from: http://web.ng.undp.org/mdgs/MDG-Count-Downstrategy-report.pdf, accessed: 25 May, 2015.

[34] Government of the Federal Republic of Nigeria, Nigeria millennium development goals: Report 2010, 2010. Retrieved from:

http://www.sparc-

nigeria.com/RC/files/4.2.1_Nigeria_Millennium_Development_Goals_Report_2010.pdf, accessed: 15 May, 2015.

[35] AFRODAD, The politics of the MDGs and Nigeria: A critical appraisal of the global partnership for development (Goal 8), AFRODAD, Harare, Zimbabwe, 2005.

[36] UN, Millennium Development Goals: 2013 Progress Chart, 2013. Retrieved from: http://www.un.org/millenniumgoals/pdf/report-2013/2013_progress_english.pdf, accessed: 4 June, 2015. 